\title{
THE ROLE OF NON-STRESS TEST TO DECISION-MAKING PROCEDURE IN PREGNANT WOMEN WITH CESAREAN DELIVERY "OUTCOMES OF OUR CLINIC AND LITERATURE REVIEW"
}

\author{
Bulent ERGUN, Serhat SEN, Yusuf KILIC, Oguzhan KURU, Mehmet OZSURMELI \\ ${ }^{1}$ Department of Gynecology and Obstetric, Istanbul University, Faculty of Medicine, Istanbul, Turkey
}

\begin{abstract}
SUMMARY
Introduction: Non-stress test (NST) became the basic method to increase fetal survival rates during over 4 decades. Although the accuracy of fetal well-being assesmernt of the method still remains controversial. The basic goal is to predict fetal hipoxia and severe asphyixia and intervene before fetal death happens. On the other hand, prenatal outcome does not improve as desired due to discordance between NST findings and severity of fetal hipoxia. Aim: To determine the power of decision-making role of NST, via retrospective datas of cesarean deliveries indicated with fetal distress according to NST findings.

Materials and methods: In Istanbul Medical Faculty Hospital, the datas of 590 cesarean deliveries indicated with fetal distres according to NST findings, between the dates of 2007-2009 were detected retrospectively. Cases were divided into two groups as preterm and term labors. The postpartum term datas selected were; birth weight, APGAR scores of 1 st and 5th minutes, cord blood $\mathrm{pH}, \mathrm{pH}, \mathrm{pO} 2, \mathrm{pCO} 2, \mathrm{HCO}$, base excess (BE). As measuring the value of NST to predict fetal hipoxia, positive predictive value was calculated. As for APGAR scoring; positive and negative predictive values, spesificity, sensitivity were calculated.

Result: NST was not found as effective as it was obtained. Only 30\% of the cases were found hipoxic. Additionally between those fetuses with hipoxia, 38\% had 1st minute APGAR score of 7 (cut-off value) and under. Although in cases with findings of uteroplacental insufficiency NST should give much valuable information, regarding to increase of unnecessary surgical procedures. On the other hand, concept of guideness of NST to operative labor seems to be logical considering medicolegal issues.
\end{abstract}

Key words: APGAR scoring, non-stress test, umblical cord blood $\mathrm{pH}$

Journal of Turkish Society of Obstetrics and Gynecology, (J Turk Soc Obstet Gynecol), 2012; Vol: 9 Issue: 1 Pages: 59 - 64

\section{FETAL DISSTRES ENDİKASYONUYLA SEZERYAN DOĞUM YAPMIŞ OLGULARDA NON-STRES TESTIN KARAR VERMEDEKİ ROLÜ "KLİNIĞGiMIZİN VERILERİ VE LITTERATÜR DERLEMESI"}

\begin{abstract}
ÖZET
Giriş: Non-stres test fetal sağkalımı artırmak için yaklaşık 4 dekattır kullanılan temel yöntemdir. Buna rağmen bu yöntemin fetal iyilik halini değerlendirmedeki etkinliği halen tartışmalıdır. Temel amaç fetal hipoksiyi tanımak ve ciddi asfiksi ve ölüm gelișmeden duruma müdahale etmektir. Ancak fetal kalp atım hızının monitorizasyonu her zaman hipoksinin şiddeti ile korele olmadığı için operatif doğum oranları artmakla birlikte neonatal sonuçlar bu artışa zannedildiği oranda olumlu yansimamaktadır.
\end{abstract}

Address for Correspondence: Dr. Bülent Ergun. İstanbul Tıp Fakültesi, Kadın Hastalıkları ve Doğum Anabilim Dalı, İstanbul Phone: +90 (532) 2772400 e-mail: bergyn@uydunet.net

Received: 28 March 2011, revised: 09 September 2011, accepted: 20 September 2011, online publication: 08 December 2011 
Amaç: Kardiyotokografik olarak fetal distres tanısı konularak sezeryan endikasyonu verilen olguların retrospektif olarak taranıp postpartum kan gazı ve APGAR skoru referans alınarak NST'nin fetal iyilik halini göstermedeki doğru karar verdirici rolünü değerlendirmek.

Gereç ve yöntemler: İstanbul Tip Fakültesi Hastanesi'nde 2007-2009 yılları arasında NST' ye göre fetal distres endikasyonuyla sezeryan yapılan 590 olguya ait veriler retrospektif olarak tarand. Olgular kendi içinde doğum zamanına göre preterm ve term olmak üzere iki gruba ayrıldı. Postpartum dönemde kaydedilen verilerden doğum kilosu, 1.ve 5. dakika APGAR skoru, kordon kanı pH, pO2, pCO2, HCO3, baz excess (BE) değerleri tarandı. Istatistiksel olarak NST'nin fetal distres endikasyonu koymadaki pozitif prediktif değeri ve kontrol yöntemi olarak Apgar skorlamasının sensitivite, spesivite, pozitif ve negatif prediktif değerleri taranan parametreler esas alınarak analiz edildi.

Sonuç: NST çeşitli nedenlerle tek başına fetal iyilik halini göstermede tahmin edildiği kadar başarılı bulunmamıştır. Bu bağlamda fetal distres tanısı konulan fetüslerin aslında \%30 kadarında fetal hipoksi olduğu saptandı (pH<7.20). Fetal hipoksi gözlenen grubun \%38' lik bölümünde 1. Dakika Apgar skoru cut-off değer olan 7' nin altında bulundu. Buna rağmen uteroplasental yetmezlik başta olmak üzere fetal hipoksiyle seyreden risk grubundaki hastalarda fetal iyilik halinin saptanmasında kullanışlı olmakla birlikte klinisyeni pekçok nedenle operatif doğuma yönlendirmesi ve gereksiz müdahale sıklığındaki artış dikkat çekici bulunmuştur. Ancak medikolegal sorunlar göz önüne alındı̆̆ında halen NST' nun en sık ve yaygın kullanılan yöntem olması kabul edilebilir görünmektedir.

Anahtar sözcükler: APGAR skorlaması, non-stres test, umblikal kordon kanı pH

Türk Jinekoloji ve Obstetrik Derneği Dergisi, (J Turk Soc Obstet Gynecol), 2012; Cilt: 9 Sayl: 1 Sayfa: 59-64

\section{INTRODUCTION}

The purpose of fetal monitoring during delivery process to identify fetal hypoxia and perform the appropriate interventions before the development of severe asphyxia.

The basic principle of NST is to use as a crtiteria in evaluaiton of basal heart rate, variability, reactivity, the possible relationship between contractions and decelerations and fetal well-being in brief. Gestational weeks and the presence or absence of growth retardation must be taken into account in the interpretation of the parameters $^{(1)}$. Fetal heart rate monitoring is fetal brain monitoring actually. Fetal brain responds to central and peripheral stimuli by changing the heart rate time to time. These stimuli are received directly by the chemoreceptors, baroreceptors and in response to the brain's own metabolic changes. This is why, the fetal heart rate changes related to so many non-hypoxia stimuli, even as secondary to the heart's own physiology. This fact also explain us the most basic proposal of CTG; if the fetal heart rate is normal in monitoring, it means good oxygenation of the fetus; if there is a problem with trace, it could be influenced not only by hypoxia but also many variables so it does not point to a definite prediction. The point obstetrician have failed in this regard is that mechanism of fetal response to the stimuli of hypoxia and other than hypoxia have not been completely understood ${ }^{(2)}$. At this point the clinician have a significant problem. How and when should we intervene to the process of birth while lack of the confidence in NST? Making decision of operative delivery depending on the fetal stress does not reflect positively in the neonatal outcomes as previously thought. Although outcomes vary in different series, with an average of $50 \%$ rate, acidosis and low APGAR score have not been seen in ceserean delivery performed in the direction of this decision ${ }^{(3-7)}$. As the electronic heart rate monitoring in clinical use become more prevalent, rates of operative delivery increased, but there was no significant change in neonatal outcomes. In the initial studies in which the accuracy of fetal distress was questioned as an indication for caesarean section; $\mathrm{pH}$ and acid-base values of the postpartum cord blood were analyzed in order to document the post-partum fetal hypoxia and over time these parameters have been adopted as the standard objective control method in terms of post-partum evaluation of $\mathrm{NST}^{(8,9)}$. In addition, developed to determine the need for neonatal resuscitation and with more expectation than a practical clinical method, APGAR score, NST was accepted as the control criterion. However, It is recommended that APGAR score alone is not enough to evaluate neonatal asphyxia, blood gas analysis should 
be done for a more objective evaluation ${ }^{(10)}$.

In this study,we scan the datas of the patients who are given an indication of fetal distress for caesarean section in the last three years in our clinic, rectospectively and we needed to examine predictive value and the role of NST in decision-making in accordance with the existing literature.

\section{MATERIALS AND METHODS}

\section{Design of study}

It is designed as a Retrospective Cohort Study.

\section{Selection of patients and Clinic Protocols}

590 ceserean delivery cases with the indication of fetal distress according to NST were retrospectively reviewed between the years 2007-2009 in our clinic. In 4 delivery room, 4 observation and 2 intensive care beds; during antepartum and intrapartum monitoring, the cases with late deceleration, fetal bradycardia, persistent atypical variable deceleration, baseline tachycardia with the loss of variabilite were evaluated by the current physician in accordance with National Institute of Child Health and Human Development Research Planning Workshop guide(11), and ceserean delivery decision with the indication of fetal distress have been given afterwards. Realized from the moment of decision at the latest within 30 minutes of birth. In accordance with our routine clinical practice for all cases, after removal of the placenta and cord clamped at two points $10 \mathrm{~cm}$ apart; a sufficient amount of heparinized blood were obtained and delivered to laboratory within at latest 5 minutes for blood gas analysis. (Copenhagen Radiometer PICO 70) (Radiometer Copenhagen ABL 510 Blood Gas System). In operation room, the first assessment of newborns were made by pediatricians and APGAR 1 and 5 score were determined.

\section{Basic Criteria}

The cases were divided into two main groups according to $\mathrm{pH}$ values those above and below 7,2 that considered the normal $\mathrm{pH}$ of cord blood gases. $\mathrm{pH}<7$ was considered as severe acidosis ${ }^{(16)}$. In all samples $\mathrm{pO}$, pCO2, $\mathrm{HCO} 3$, APGAR score, gestational age, birth weight parameters were studied. Pathologic limits were accepted as in Table I values. Data of the fetus below and above 34. week were also analyzed as the gestational age of pregnancy (maturity) were considered to be an independent factor.

Table I: Referanced Cut off Values $(12,13)$

\begin{tabular}{ll}
\hline $\mathrm{pH}$ & $<7.20$ \\
$\mathrm{pO} 2(\mathrm{mmHg})$ & $<10$ \\
$\mathrm{pCO} 2(\mathrm{mmHg})$ & $>55$ \\
$\mathrm{HCO}(\mathrm{mMol} / \mathrm{L})$ & $<18$ \\
Base deficit $(\mathrm{mEq} / \mathrm{L})$ & $<-10$ \\
Gestational age & $<34$ \\
\hline
\end{tabular}

\section{Statistics and analysis}

The average value, minimum and maximum values of all the data were calculated. NST's positive predictive value in detecting fetal hypoxia and as a method of control; sensitivity, specificity and positive predictive value of Apgar scoring were calculated in the formula below.

\begin{tabular}{|c|c|c|}
\hline & Disease (+) & Disease (-) \\
\hline Test (+) & $\mathbf{A}$ & B \\
\hline Test (-) & $\mathbf{C}$ & D \\
\hline sensitivity & \multicolumn{2}{|c|}{$\mathrm{A} / \mathrm{A}+\mathrm{C}$} \\
\hline specificity & \multicolumn{2}{|c|}{$\mathrm{D} / \mathrm{B}+\mathrm{D}$} \\
\hline Positive predictive value & \multicolumn{2}{|c|}{$\mathrm{A} / \mathrm{A}+\mathrm{B}$} \\
\hline
\end{tabular}

\section{Results}

232 (39\%) of the total 590 cases were below 34 weeks, the average was 29.83 (24-34)weeks, the average birth weight was $1211 \mathrm{gr}$, the average APGAR score 1.minute was 6.45 , 5.minute was 8,05 . Blood gas data of this group are shown in Table III. In all cases, the average gestational week was 35 (24-42), birth weight was 2001gr (400-4400), 1-5th minute APGAR was 7.14 (1-10), 8.65 (6-10); $\mathrm{pH}: 7.23$ (6.69-7.55), pO2: 27.3mmHg (3.3-89.4), pCO2: 62.5mmHg (22.8-83.4), HCO3: $22.97 \mathrm{mmol} / \mathrm{L}(0.8-48.6)$, base excess (BE): -5.54 $\mathrm{mEq} / \mathrm{L}(-30.4-1)$. In 413 of the cases(\%70) $\mathrm{pH}$ was above 7.20 , severe acidosis $(\mathrm{pH}<7)$ were present in 30 cases of those below 7,20.

Table II: the average of cord blood gas data below the gestational week 34. $(n=232)$.

\begin{tabular}{ll}
$\mathrm{pH}$ & 7.21 \\
$\mathrm{pO} 2(\mathrm{mmHg})$ & 26.60 \\
$\mathrm{pCO} 2(\mathrm{mmHg})$ & 63.8 \\
$\mathrm{HCO} 3(\mathrm{mMol} / \mathrm{L})$ & 20.80 \\
$\mathrm{BE}(\mathrm{mEq} / \mathrm{L})$ & -5.97 \\
\hline
\end{tabular}


According to detailed analysis of blood gases in acidotic $(\mathrm{pH}<7,20)$ fetuses, 50\% $(\mathrm{n}=177)$ was respiratory, $42 \%$ mixed, and the remaining section $(8 \%)$ were identified as metabolic acidosis.

The average neonatal outcomes according to $\mathrm{pH}$ values of fetuses are detailed in Table III.

Table III: PH values on average than fetuses with neonatal outcomes*. gestational weeks, median and standard deviation values are presented

\begin{tabular}{llll}
\hline & $\begin{array}{l}\text { pH>7.20 } \\
\mathbf{n : 4 1 3}\end{array}$ & $\begin{array}{l}\mathbf{p H} \mathbf{7 . 2 0}- \\
\mathbf{7 . 0} \text { arası } \\
\mathbf{n : 1 4 7}\end{array}$ & $\begin{array}{l}\mathbf{p ~} \mathbf{H}<\mathbf{7 . 0} \\
\mathbf{n : 3 0}\end{array}$ \\
& & 1837 & 1917 \\
\hline Weight (gr) & 2081 & 34.54 & 33.3 \\
GH* & 34.72 & $6.62 \pm 0,82$ & $5.2 \pm 0,62$ \\
Apgar 1** & $7.34 \pm 0,95$ & $8.25 \pm 1,1$ & $6.3 \pm 0,85$ \\
Apgar 5** & $8.55 \pm 1,3$ & &
\end{tabular}

*: Gestational weeks

The relationship between Apgar scores and blood gas $\mathrm{pH}$ value is given in Table IV. Accordingly, the sensitivity of Apgar score in determining fetal hypoxia to $38 \%$, specificity $94 \%$, positive predictive value $76 \%$, negative predictive value was $65 \%$.

Table IV: The relationship between Apgar scores and blood gas pH value.

\begin{tabular}{lll}
\hline & $\mathbf{p H}<\mathbf{7 . 2 0}$ & $\mathbf{p H}>\mathbf{7 . 2 0}$ \\
\hline Apgar $<7$ & 69 & 21 \\
Apgar $>7$ & 108 & 392 \\
\hline
\end{tabular}

$n=590$, Apgar 1 is the value of minutes.

Accordingly, NST's positive predictive value in detecting fetal hypoxia was found to be $30 \%$.

\section{DISCUSSION}

Randomization was not achieved due to the retrospective design of study, but the excess number of patients were considered qualified interpretation. Similar studies in the literature, Steer et al. ${ }^{(14)}$ evaluated 698 cases and found positive predictive value of NST pathology in detecting the acidosis $(\mathrm{pH}<7.17)$ is $47 \%$. Van den Berg et al. ${ }^{(15)}$ evaluated 2659 cases on a retrospective studies and found positive predictive value of NST pathology in detecting the acidosis ( $\mathrm{pH}<7.17$ ) is $29 \%$. Our study results were consistent with the literature.
It is known that fetal heart rate is the first distorted parametre when the fetal hypoxia develops. the most valuable parameters showing of the fetal intrapartum well-being in NST is considered to be the normal baseline fetal heart rate and a normal beat to beat fetal heart rate variability ${ }^{(16)}$. Here although NST's high sensitivity seems to be an advantage, progress to fetal distress from normal electronic fetal monitor trace can be quickly and secretly, depending on the cause. While umbilical cord prolapse can lead to sudden symptoms of fetal distress with a deep bradycardia, on the other hand in case of utero-placental insufficiency, fetal distress can occur slowly during the hours of labor.

In study, diagnostic features as the criterion of fetal distress in NST were not classified on itself. Here, the question of the accuracy of the concept of fetal distress and which patterns of NST may show hypoxia and asphyxia in fact, was encountered. Signs of fetal distress in NST are known to be reverseble except the minute fetal heart rate $<70$ and loss of variability with prolonged decelerations $^{(8)}$. For this reason, American College of Obstetricians and Gynecologists (ACOG) abandoned the terminology of fetal distress and suggest a more accurate term of non-reactive $\mathrm{NST}^{(17)}$. The most important disadvantage of the widespread use of NST is the increase in operative delivery rate and in order to avoid this problem and to be more accurate documentation of fetal well-being, a series of control method were studied . Fetal scalp pH could not be used in a widespred area because of the busy delivery room conditions, high probability of techniqual mistekes, patients discomforting and need to repeat sampling, however it is observed that in experimental use it does not decrease operative delivery rates ${ }^{(18)}$. Use of fetal pulse oksimetre method which is approved by the Food and Drug Administration (FDA) in 2000 showed decrease in caesarean rates in case of unreliable NST,moreover it is detected that inlong term follow up of fetuses with $>30 \%$ of oxygen saturation has no negation ${ }^{(19)}$. However, anticipating further study is needed right now in terms of reliability and efficacy, ACOG currently does not recommend this method. Another control method - fetal electrocardiography (ECG)-, in a multicenter randomized controlled study (20) the use of ST analysis of fetal ECG with the NST reduced development of metabolic acidosis rates and caesarean section rates minimally but identified statistically significant. 
On the other hand, 2 / 3 of newborn babies with umbilical artery $\mathrm{pH}<7.0$ don't have brain dysfunction and its clinical signs ;even occurs, it may be temporary $(21,22)$. and it is known that, electronic heart rate monitoring can still have great importance in legal perspective. Obstetricians and staff of hospitals are under this legal pressure so it affects the rate of caesarean section.

Data of the Apgar scoring system, evaluated in the study was found similar with literature $(23,24)$. Here, the Apgar score were confirmed to be most affected data by the gestational week. Although low Apgar score lead to false positivitiness due to the extrautero conditions and prematures, so that ,absence of umbilical artery acidosis even rules out the presence of asphyxia, physician should pay attention to other causes of neonatal depression ${ }^{(25)}$. Routine Apgar scoring is found to be beneficial in this respect.

\section{Summary}

The various data prevent consensus but the contribution of EFM to determination of fetal well-being and neonatal outcomes are less than expected and the most significant risk increase of the operative delivery. In our study, the predictive role of NST in determining fetal hypoxia was found $30 \%$. However, in the case of unreliable NST, the physician's interventions before the development of asphyxia with the possibility of hypoxia, indicate right thing to do in the legal perspective?. At this stage, in the management of unreliable NST, the methods that we mentioned above and yet undefined must be advanced as soon as possible.

\section{REFERENCES}

1. Odendall H. Fetal heart rate patterns in patients with intrauterine growth retardation. Obstet Gynecol 1976; 48: 187- 90

2. Steven Gabbe, MD Jennifer Niebyl, MD Joe Leigh Simpson, MD, Gabbe: Obstetrics: Normal and Problem Pregnancies, 5th ed. 2007 Churchill Livingstone, An Imprint of Elsevier.

3. Havercamp AD, Thompson HE, McFee JG, Cetrulo C. The evaluation of continuous fetal heart rate monitoring in high risk pregnancy. Am J Obstet Gynecol 1976; 125: 310- 7.

4. Renou P, Chang A, Anderson I, Wood C. Controlled trial of fetal intensive care. Am 7 Obstet Gynecol 1976; 126: 470- 6

5. Kelso IM, Parsons RJ, Lawrence GF, Arora SS, Edmonds DK, Cooke ID. Continuous fetal heart rate monitoring in labor. Am 7 Obstet Gynecol 1978; 131: 526- 31 .

6. Havercamp AD, Orleans M, Langendoerfer S, McFee J, Murphy J, Thompson HE. A controlled trial of the differential effects of intrapartum fetal monitoring. AmJ Obstet Gynecol 1979; 134: 399- 412.

7. Wood C, Renou P, Oats J, Farreli E, Beischer N, Anderson I. A controlled trial of fetal heart rate monitoring in a low risk obstetric population. Am J Obstet Gynecol 1981; 141: 527- 624.

8. Tejani N, Mann LI, Bhakthavathsalan A. Correlation of fetal heart rate patterns and fetal $\mathrm{pH}$ with neonatal outcome. Obstet Gynecol 1976; 48: 460- 3 .

9. Liu DTY, Thomas G, Blackwell RJ. Progression in response patterns offetal heart rate throughout mlabour. Br J Obstet Gynaecol 1975; 82: 943- 51.

10. Martin GC, Green RS, Holzman IR. Acidosis in newborns with nuchal cords and normal apgar scores. J Perinatol 2005; 25: $162-5$.

11. Electronic fetal heart rate monitöring: research guidelines for interpretation. National Institute of Child Health and Human Development Research Planning Workshop. Am J Obstet Gynecol 1997; 177: 1385- 90 .

12. Jack N, Blechner MD: Maternal-fetal acid-base physiology. Clin Obstet Gynecol 1993; 36: 30.

13. John WC, Johnson MD: Umbilical blood acid-base analysis, dm Obstet Gynecol 1993; 36: 1 .

14. Steer PJ, Eigbe I, Lissauer TS, Beard RW; Interrelationships among abnormal cardiotocogram in labor, meconium staining of the amniotic fluid, arterial cord blood $\mathrm{pH}$ and Apgar scores. Obstet Gynaecol 1989; 74: 715.

15. Van Den Berg P, Scnmidt S, -Gesche J, Saling E: Fetal distress and the condition of the newborn using cardiotocography and fetal blood analysis during labor. Br J Obstet Gynecol 1987; 94: 72 .

16. Paul RH, Suidan AK, Yeh S, Schifrin BS, Hon EH.Clinical fetal monitoring.VII. The evaluation and significance of intrapartum baseline FHR variability. Am j Obstet Gynecol 1975; 123: 206- 10 .

17. American College of Obstetricians and Gynecologists: Fetal Distress and Birth Asphyxia. Washington, DC, American College of Obstetricians and Gynecologists, ACOG Committee Opinion 137.

18. Goodwin TM, Milner-Masterson C, Paul R.: Elimination of fetal scalp blood sampling on a large clinical service. Obstet Gynecol 1994; 83: 971.

19. Garite TJ, Dildy GA, McNamara $\mathrm{H}$ et al: A multicenter controlled trial of fetal pulse oximetry in the intrapartum management of non-reassuring fetal heart rate patterns. Am J Obstet Gynecol 2000; 183: 1049. 
20. Amer-Wahlin I, Hellsten C, Noren H, et al: Cardiotocography only versus cardiotocography plus ST analysis of fetal electrocardiogram for intrapartum fetal monitoring: a Swedish randomised controlled trial. Lancet 2001; 358: 534.

21. Goldaber KG, Gilstrap LC 3rd; Leveno KJ, Dax JS. Pathologic fetal acidemia.Obstet Gynecol 1991; 78(6): 1103- 7.

22. Andres RL, Saade G, Gilstrap LC, Wilkins I, Witlin A, Zlatnik F, Hankins GV. Association between umbilical blood gas parameters and neonatal morbidity and death in neonates with pathologic fetal acidemia. Am J Obstet Gynecol 1999; 181:
867- 71 .

23. Fields IM, Entman SS, Boehm FH: Correlation of one minute Apgar score and the $\mathrm{pH}$ value of umbilical arterial blood. South Med J 1983; 76: 1477.

24. Boehm FH, Fields L: Correlation of the one minute Apgar score and umbilical cord acid-base status. South Med J 1986; 79: 429.

25. Johnson JWS, Richard DS: The case for rutine umbilical blood acid-base studies at delivery. Am J Obstet Gynecol 1990; 162: 621 